\title{
PHENOTYPIC AND GENOTYPIC VARIANCE AND HERITABILITY OF STAY GREEN CHARACTER AMONG 22 ELITE SORGHUM (Sorghum bicolor(L.) Moench) GENOTYPES
}

\author{
Anas $^{1}$, Meddy Rachmadi ${ }^{1}$, Mansyur $^{2}$ \\ ${ }^{1}$ Faculty of Agriculture, Padjadjaran University. \\ 2 Faculty of Animal Husbandry, Padjadjaran University \\ Correspondence author: anasyayak@yahoo.com
}

\begin{abstract}
Delaying of leaf senescence (stay green) is an effective strategy for increasing of crop yield, particularly under water-limited conditions. Study of genotypic variance of stay green is very useful for breeding program of stay green character. Replicated field experiment was carried out in Farm Experimental Station, Faculty of Agriculture Padjadjaran University during dry season. The objectives of this study were: i) to estimate genotypic and phenotypic variances of stay green character; ii) to evaluate and investigate stay green performance of the 22 elite sorghum genotypes. High genotypic and phenotypic variances were observed for plant morphology (plant height, stem diameter), leaf morphology (leaf number, leaf width, leaf length and total leaf area) and yield component (panicle length) and were supported by high estimation of heritability value. Corresponding heritability ranged between 0.77 and 0.94 . Genotypic variance of stay green characters was narrow and estimation of broad sense heritability was low. Stay green characters in sorghum might be a quantitative character that was controlled by many genes. Unpad 1.3, Unpad 1.1 and 1090 genotype showed good performance for stay green character. These genotypes can be recommended as stay green parental in breeding program.
\end{abstract}

Key words: Genotypic variance, Heritability, Phenotypic variance, Sorghum, Stay green

\section{INTRODUCTION}

Sorghum is not a new plant in Indonesia and is known already with different name in some region of Indonesia (Anas, 2007). However, sorghum has not been intensively planted in Indonesia. Sorghum could be used either as an alternative food or as bio-ethanol production in some countries (Hoshikawa, 1990; Jorapur \& Rajvanshi, 1991). Sorghum is more tolerant to drought than other crop plants (Murty \& Kumar, 1995; Metcalfe \& Elkins, 1980) and sorghum is very suitable for Indonesia because growth rate of marginal land in Indonesia was very high every year (Anas et al., 2007).

Delaying of senescence or stay green character is an important character because it can improve adaptation of plant to drought especially after flowering (Rosenow \& Clark, 1981), lodging resistance and disease resistance to Macrophominia phaseolina (Tassi) Goid (Mughogho \& Pande, 1984). Stay green is also associated with level of carbohydrate content in stem and increase of grain filling period of plant in water stress condition (Borrell \& Douglas, 1996). Breeding programs for stay green character has been done in United States (Rosenow et al.,1983) and Australia (Henzell et al., 1992). Stay green plants showed higher total biomass than those did not have stay green character. Stay green plants can store more food in their stem (Borrell et al., 2000a). Stay green plants showed also high concentration of leaf nitrogen and were associated with a higher efficiency in transpiration (Borrell et al., 2000b). 
Genotypic variance and heritability are very useful genetic parameters that determine effectiveness of selection process in plant breeding program (Sleper \& Poehlman, 2006). Some of cereal crops show genetic variation of leaf senescence during grain filling period (Thomas \& Smart, 1993). Sorghum show also variation for stay green character, and is strongly influenced by environment and genetic background of plant (Thomas \& Howarth, 2000). There is considerable genetic diversity of sorghum (Anas \& Yoshida, 2004, Murray et al., 2009; Shehzad et al., 2009) and gene control of leaf senescence (See) has been cloned successfully from several plant species. Homologous genes See also has been isolated from several plant fruits and part of flowers of some plants (Nam, 1997; Medina-Sua'rez et al., 1997).

Broad genetic background of elite sorghum genotypes was used in field experiment to study variability and heritability of stay green character. These elite sorghum genotypes have been collected from diverse research center and had been bred from different genetic background of parents (Anas \& Yoshida, 2000). Objectives of this study were: a) to estimate genotypic variance and heritability of stay green character, b) to evaluate performances of stay green character of some elite sorghum genotypes.

\section{MATERIALS AND METHODS}

\section{Experimental design, Genetic materials and Observation}

Field trial was arranged in Randomized Complete Block Design with two replications at the experimental farm station of Faculty of Agriculture, Padjadjaran University (Unpad), Jatinangor West Java. Treatments consist of 22 elite sorghum genotypes of Plant Breeding Lab. Faculty of Agriculture Unpad (Table 1). Planting space was $10 \mathrm{~cm} \times 75 \mathrm{~cm}$ with a distance of $1 \mathrm{~m}$ between plots.

Data were recorded for 11 characters consisting of morphological and physiological characteristics. Total leaf area of sorghum was measured as a function of the sixth leaf using equation TLA $=14.355\left(\mathrm{SLA}_{\mathrm{LW}}\right)^{0.857}$ (Chinnamuthu et al., 1989). $S L A_{\mathrm{LW}}$ is the sixth leaf area (maximum length multiplied by maximum width) of sorghum plants. Analysis of stay green character was estimated from component of leaf color (LC). Brightness and color of sixth leaf was measured using Digital Color Analyzer tool on three primary colors Red-GreenBlue. The data were then processed using the Color Picker (Adobe Photoshop CS.3 Version 10.1, 1990-2007). RGB values obtained were then plotted in 3D graphics using SPSS Ver. 16.0.1 (2007).

Table 1. Material genetic in field experiment

\begin{tabular}{llllll}
\hline $\mathrm{Nr}$ & Genotype & Note and collected source & $\mathrm{Nr}$ & Genotype & Note and collected source \\
\hline 1 & Numbu & Released in 2001, Maros & 12 & Wray & Sweet sorghum, Jepang \\
2 & UPCA-S1 & Released in 1972, Maros & 13 & Cantel & Local variety, Maros \\
3 & Kawali & Released in 2001, Maros & 14 & II-24 & Elite genotype, Unpad \\
4 & Unpad 1.1 & Variety, Unpad & 15 & 10.1 & Elite genotype, Unpad \\
5 & B.100 & Vaeriety, BATAN & 16 & 10.2 & Elite genotype, Unpad \\
6 & 4.1 & Elite genotype, Unpad & 17 & 2.1 & Elite genotype, Unpad \\
7 & 1090 & Elite genotype, Maros & 18 & 2.2 & Elite genotype, Unpad \\
8 & ICR 3 & Elite genotype, ICRISAT India & 19 & Keller & Sweet sorghum, Jepang \\
9 & Super Sorgo & Sweet sorghum, Jepang & 20 & Batari & Variety, Maros \\
10 & I-34 & Elite genotype, Unpad & 21 & Unpad 1.3 & Elite genotype, Unpad \\
11 & Big S. Sugar & Sweet sorghum, Jepang & 22 & Taomitsu & Sweet sorghum, Jepang \\
\hline
\end{tabular}




\section{Statistical Analysis}

Differences among genotypes were analyzed by Scott Knott test (Gaspersz, 1995). Phenotypic $\left(\sigma_{f}^{2}\right)$ and genotypic variance $\left(\sigma_{g}^{2}\right)$ and heritability were estimated based on value of expected mean square according Singh and Chaudhary (1979) and Bos \& Caligari (1995). Criteria of heritability were estimated according Stansfield (1991). Phenotypic and genotypic variance was then compared with twice of standard deviation values of genotypic and phenotypic variance. Standard deviation of the phenotypic variance and genotypic variance was calculated according Anderson and Bancroft (1952) cited Pinaria et al. (1997) and Wahdah et al. (1996).

\section{RESULTS AND DISCUSSION}

The data collected were subjected to ANOVA using SPSS for assessment of the stay green genotypes. Genotypic differences were highly significant for all characters observed except leaf color $(\mathrm{G})$, leaf brightness and chlorophyll content. Number of leaf $(\mathrm{NL})$, leaf length (LL), leaf width (LW) and total leaf area (TLA) showed wide genotypic and phenotypic variance (Table 2). Genotypic variance is one of the genetic parameters that determine effectiveness of selection process in plant breeding program (Sleper \& Poehlman, 2006). Effectiveness of selection process of a character depends on environmental effect for these characters. Morphological characters of leaf showed high estimation of heritability values (Table 2). This suggested that the diversity of leaf morphology was mainly due to genetic factors and selection was more effective on these characters.

Sweet sorghum and white grain sorghum Unpad 1.1 showed higher number of leaf than Batari, Numbu, Cantel and B100 genotypes (Table 3). The NL character determined crop canopy (TLA) that was associated with evapotranspiration and photosynthesis activity of plants (Arkin et al., 1983). Improvement of TLA character will increase wide of crop canopy that will enhance absorption of sunlight by plants, which in turn will increase rate of transpiration and photosynthesis process. It will also reduce evapotranspiration from soil so will keep moisture of soil.

Many researchers used TLA character as indicator for studying of stay green character in sorghum. Stay green character in sorghum is often associated with tolerance to drought stress after flowering (post-flowering drought tolerance) (Xu et al., 2000). Slowing of senes-

Table 2. Genotypic and phenotypic variance and estimation of heritability of some characters

\begin{tabular}{lllllll}
\hline Character & $\sigma_{\text {gen }}^{2}$ & Criteria & $\sigma_{\text {phe }}^{2}$ & Criteria & $\mathrm{H}$ & Criteria \\
\hline Leaf number & 0.99 & $\mathrm{H}$ & 1.20 & $\mathrm{H}$ & 0.83 & $\mathrm{H}$ \\
Leaf width (cm) & 0.63 & $\mathrm{H}$ & 0.95 & $\mathrm{H}$ & 0.66 & $\mathrm{H}$ \\
Leaf length (cm) & 81.18 & $\mathrm{H}$ & 96.05 & $\mathrm{H}$ & 0.84 & $\mathrm{H}$ \\
Total leaf area (cm2) & 290727.00 & $\mathrm{H}$ & 379725.80 & $\mathrm{H}$ & 0.77 & $\mathrm{H}$ \\
Leaf color (green) & 50.96 & $\mathrm{M}$ & 238.16 & $\mathrm{H}$ & 0.21 & $\mathrm{M}$ \\
Leaf brightness & 2.84 & $\mathrm{M}$ & 26.21 & $\mathrm{H}$ & 0.19 & $\mathrm{~L}$ \\
Chlorophyll content (unit) & 36.98 & $\mathrm{M}$ & 162.20 & $\mathrm{H}$ & 0.23 & $\mathrm{M}$ \\
Plant height (cm) & 2804.72 & $\mathrm{H}$ & 2971.95 & $\mathrm{H}$ & 0.94 & $\mathrm{H}$ \\
Stem diameter (cm) & 0.05 & $\mathrm{H}$ & 0.07 & $\mathrm{H}$ & 0.69 & $\mathrm{H}$ \\
Panicle length (cm) & 12.00 & $\mathrm{H}$ & 14.23 & $\mathrm{H}$ & 0.84 & $\mathrm{H}$ \\
Seed weight plant-1 (g) & 146.44 & $\mathrm{~L}$ & 368.27 & $\mathrm{H}$ & 0.39 & $\mathrm{M}$ \\
\hline
\end{tabular}

Note: $\sigma_{\text {gen }}^{2}=$ genotypic variance; $\sigma_{\text {fen }}^{2}=$ phenotypic variance; $H=$ heritability; $H=H i g h ; L=$ low; $M=$ medium. 
cence is one of effective strategies to increase yields of cereal crop in water-stress condition. There were association between stay green and grain yield that was affected by environment and genetic background of plant (Jordan et al., 2012). Five sweet sorghums showed good TLA and not significantly different with superior grain sorghum genotypes Unpad 1.1 or Unpad 1.3 (Table 3). Super Sorgo showed the highest TLA character and followed by 2.1 and UPCA-S1 genotype. On the other hand, I-34, II-24, ICR3, Batari and Cantel cultivars showed low TLA character.

Low genotypic variance was exhibited by components of stay green character, such as green component of leaf color (LC). Heritability of green component of LC, chlorophyll content (CC) of leaf and leaf brightness (LB) were relatively low (Table 2). This suggested that effect of environment was high to components of stay green character and selection for these characters were less effective. Stay green characters in sorghum might be a quantitative character that was controlled by many genes and was strongly influenced by environmental factors. Some researchers reported that many genes scattered in several places in sorghum genome controlled stay green character.

Stay green character of some plants was controlled by See gene (Nam, 1997; MedinaSua'rez et al., 1997). However, a lot of research on genetic control of stay green character used QTLs approach in their study (Subudhi et al., 2000; Borrel et al., 2000a; Tao et al., 2000). Kebede et al. (2001) have reported nine QTLs in seven-linkage group of sorghum genome associated with stay green character. While four QTLs (Stg1, Stg2, Stg3 and Stg4) correlated with stay green character and Stg2 QTL was most important in controlling stay green characters in sorghum (Harris et al., 2006). Stay green character and some components of stay green character was controlled by additive gene (Borrel et al., 2000a) and was associated with multiple locations of linkage group B and I of sorghum genome (Tao et al., 2000).

Table 3. Performance of some characters of 22 sorghum genotypes

\begin{tabular}{|c|c|c|c|c|c|c|c|c|c|c|c|c|c|c|c|c|}
\hline \multirow{2}{*}{$\begin{array}{l}\text { Genotype } \\
\text { Numbu }\end{array}$} & \multicolumn{2}{|c|}{ LN } & \multicolumn{2}{|c|}{ TLA } & \multicolumn{2}{|c|}{ LC(G) } & \multicolumn{2}{|c|}{ LB } & \multicolumn{2}{|c|}{$\mathrm{CC}$} & \multicolumn{2}{|c|}{ PH } & \multicolumn{2}{|c|}{ SD } & \multicolumn{2}{|c|}{ PL } \\
\hline & 9 & $a$ & 3179 & $b$ & 130 & a & 52 & $a$ & 55 & a & 187 & c & 1.97 & $b$ & 20 & a \\
\hline UPCA-S1 & 11 & $b$ & 3298 & $b$ & 121 & $\mathrm{a}$ & 49 & $a$ & 36 & a & 161 & c & 2.12 & $b$ & 23 & $b$ \\
\hline Kawali & 11 & $b$ & 2565 & a & 106 & a & 43 & a & 32 & a & 157 & c & 1.81 & a & 25 & c \\
\hline Unpad 1.1 & 12 & $\mathrm{~b}$ & 3095 & $\mathrm{~b}$ & 122 & a & 49 & $a$ & 45 & $a$ & 134 & $b$ & 2.07 & b & 23 & $\mathrm{~b}$ \\
\hline B. 100 & 10 & a & 3243 & $b$ & 130 & $a$ & 52 & a & 39 & a & 170 & c & 1.86 & a & 21 & $b$ \\
\hline 4.1 & 9 & a & 2437 & a & 112 & a & 46 & a & 34 & a & 177 & c & 1.64 & a & 19 & a \\
\hline 1090 & 11 & $b$ & 3287 & $b$ & 122 & a & 49 & a & 34 & a & 243 & $d$ & 2.02 & $b$ & 23 & $b$ \\
\hline ICR 3 & 10 & $b$ & 1936 & $a$ & 118 & $a$ & 48 & $a$ & 41 & a & 112 & a & 1.69 & a & 22 & $b$ \\
\hline Super Sorgo & 11 & $b$ & 3527 & $b$ & 120 & $\mathrm{a}$ & 49 & a & 54 & a & 249 & $d$ & 2.35 & $b$ & 28 & c \\
\hline $\mathrm{I}-34$ & 8 & a & 1563 & a & 125 & $a$ & 52 & a & 34 & a & 125 & a & 1.38 & a & 16 & a \\
\hline Big Super S. & 11 & $b$ & 3202 & $b$ & 117 & $a$ & 48 & $a$ & 55 & a & 254 & d & 2.14 & b & 29 & c \\
\hline Wray & 11 & $b$ & 3120 & $b$ & 79 & $\mathrm{a}$ & 36 & a & 54 & a & 255 & $\mathrm{~d}$ & 2.36 & $b$ & 23 & $b$ \\
\hline Cantel & 10 & a & 2435 & $a$ & 106 & $a$ & 44 & $a$ & 53 & $a$ & 180 & $\mathrm{c}$ & 1.97 & b & 24 & c \\
\hline II-24 & 8 & a & 1769 & a & 121 & a & 49 & $a$ & 55 & a & 117 & a & 1.72 & a & 25 & c \\
\hline 10.1 & 11 & $b$ & 2566 & a & 120 & a & 48 & a & 39 & a & 140 & $b$ & 1.89 & a & 27 & c \\
\hline 10.2 & 10 & $b$ & 2450 & a & 118 & $a$ & 48 & $a$ & 40 & $a$ & 132 & $b$ & 1.76 & a & 22 & $b$ \\
\hline 2.1 & 9 & $a$ & 3461 & $b$ & 127 & $a$ & 51 & a & 47 & a & 243 & $\mathrm{~d}$ & 2.12 & b & 26 & $\mathrm{c}$ \\
\hline 2.2 & 11 & $b$ & 2814 & $b$ & 114 & $a$ & 47 & a & 58 & a & 131 & $b$ & 1.90 & a & 26 & c \\
\hline Keller & 11 & $b$ & 3172 & $b$ & 107 & $a$ & 44 & $a$ & 68 & a & 274 & d & 2.19 & $b$ & 24 & $b$ \\
\hline Batari & 9 & $a$ & 1997 & $a$ & 116 & $a$ & 47 & $a$ & 37 & a & 224 & d & 1.60 & $a$ & 33 & c \\
\hline Unpad 1.3 & 9 & $a$ & 3267 & $b$ & 136 & $a$ & 54 & $a$ & 37 & a & 219 & d & 1.83 & a & 22 & $b$ \\
\hline Taomitsu & 11 & $b$ & 3042 & $b$ & 100 & $a$ & 48 & $a$ & 43 & $a$ & 248 & d & 2.07 & b & 29 & c \\
\hline
\end{tabular}

Note: Value followed with same alphabet in a column show not different based on Scott-Knott test at $5 \%$ level. $\mathrm{LN}=$ leaf number; TLA=total leaf area $(\mathrm{cm} 2)$; $\mathrm{LC}(\mathrm{G})=$ green component of leaf color; $\mathrm{LB}=$ leaf brightness (unit); $\mathrm{CC}=$ chlorophyll content (unit); $\mathrm{PH}=$ plant height $(\mathrm{cm}) ; \mathrm{SD}=$ stem diameter $(\mathrm{cm})$; $\mathrm{PL}=$ panicle length (cm). 
Green components of leaf color showed no significant differences among genotypes. Differences of stay green character among genotypes could not be distinguished during field trial test. High frequency of rainfall even dry season caused small difference of $L C$ among genotypes. Stay green character will be expressed and are more pronounced among plants in water stress conditions. Plants that have no stay green character will rapidly senescence (Thomas \& Howarth, 2000). In general, elite grain sorghum genotypes of Plant Breeding Lab. Padjadjaran University showed high average of LC and LB (Table 3). Otherwise, generally sweet sorghum and released cultivars showed high chlorophyll content (CC)

Using digital color analyzer, leaf of I-34 genotype showed dark color and contribution of green color component was low (Table 3). This suggested that leaves have started to dry up and was in line with early maturity character of this genotype. Judging from percentage contribution of green color components in overall RGB system, 1090 genotype, Unpad 1.3 and Unpad 1.1 genotype showed high percentage of green color components. This suggested that these genotypes could be developed as parent in stay green breeding programs.

Percentage of green component and brightness level of Taomitsu and Wray leaves were very low. In general, sweet sorghum genotypes showed lower level of brightness than grain sorghum genotype. Sorghum leaves that were starting to dry will have lower brightness level than green leaf. However, Wray and Keller have been used as parent in breeding program for high sugar content (Murray et al., 2009).

Genotypic and phenotypic variance of plant morphology, such as plant height $(\mathrm{PH})$, stem diameter (SD), number of node (NN) and some yield components characters showed wide variability (Table 2). This was also supported by high heritability of these characters. Genotypic and phenotypic variances that were sharing value equally and well supported by high heritability value will greatly important for plant development program.

$\mathrm{PH}$ and SD character of grain sorghum were shorter and smaller significantly than sweet sorghum genotypes. According Tsuchihashi \& Goto (2005) difference of sorghum plant height was a result of increasing number of node (25\%) and $75 \%$ was result of internode elongation. According Sabadin et al. (2012) there were not associations of stay green QTL with differences in flowering time/plant height. Grain sorghum Unpad 1.1 has been bred for short plant height to facilitate harvesting process. Meanwhile, stem diameter greatly affected biomass of yield stem. According Tsuchihashi \& Goto (2004), proper cultivation techniques, spacing and planting density per unit area greatly affected process of thickening of sweet sorghum stem that determined weight of stem. Size of sweet sorghum stems was greatly influenced by four factors i.e. climate, soil type, fertilization and planting density. Additionally stem weight was strongly influenced by characteristics of stem and water availability during the growing process (Tsuchihashi \& Goto, 2005).

\section{CONCLUSION}

Generally, morphological characters of sorghum showed high genotypic and phenotypic variance and was supported by high estimation of broad sense heritability value. Genotypic variance of stay green characters was narrow and estimation of broad sense heritability was low. Unpad 1.3, Unpad 1.1 and 1090 genotype could be developed as stay green sorghum and can be used as parent in breeding program of stay green character. 


\section{REFERENCES}

Adobe Photoshop CS.3 (1990-2007). 2007. Adobe Photoshop CS3 Version 10.1. Adobe Systems Incorporated, $1990-2007$.

Anas, 2007. Development of Sorghum Crop as a Basis of Alternative Food. National Seminar on Appreciation of Sorghum Development Agriculture Department, Directorate General of Crop Plant, Directorate of Cereal Crop Indonesia. Hotel Silvia - Kupang Nusa Tenggara Timur.

Anas and T. Yoshida. 2000. Screening of Al-tolerant Sorghum by Hematoxylin Staining and Growth Response. Plant Prod. Sci. 3 : $246-253$.

Anas and T. Yoshida. 2004. Genetic Diversity among Japanese Cultivated Sorghum Assessed with Simple Sequence Repeats Markers. Plant Prod. Sci. 7:217- 223.

Anas, Sumadi and A.W. Irwan. 2007. Genetic Variability and Heritability of Important Characters of 19 Elite Sorghum (Sorghum bicolor(L.) Moench) Genotypes During Dry Season Cultivation. Proceedings of Symposium, Seminar and Congres IX Perhimpunan Agronomi Indonesia (PERAGI). Faculty of Agriculture, Universitas Padjadjaran. (Indonesia). 167 - 172.

Arkin, G.F., W.D. Rosenthal and W.R. Jordan. 1983. A Sorghum Leaf Area Model. American Society of Agricultural Engineers. St. Joseph Michigan 49085.

Borrell, A.K., and A.C.L. Douglas. 1996. Maintaining green leaf area in grain sorghum increases yield in a water-limited environment. In: Foale, M.A., R.G. Henzell, J.F. Kneipp (editors). Proceedings of the third Australian sorghum conference. Melbourne: Australian Institute of Agricultural Science, Occasional Publication No. 93.

Borrell, A.K., G.L. Hammer, and R.O. Henzell. 2000a. Does maintaining green leaf area in sorghum improve yield under drought? II. Dry matter production and yield. Crop Sci. 40. $1037-1048$.

Borrell, A.K.,Y.Z. Tao, and C.L. Mclntyre. 2000b. Physiological basis, QTL and MAS of the stay-green drought resistance trait in grain sorghum. In: J.-M. Ribaut and D. Poland (editors). Molecular approaches for the genetic improvement of cereals for stable production in water limited environments. A strategic planning work- shop held at CIMMYT, El Batan, Mexico. Mexico, CIMMYT. 142-146.

Bos, I. and P. Caligari. 1995. Selection Method in Plant Breeding. Chapman and Hall, London. $100-132$.

Chinnamutu, C.R. C. Kailasam, S. Sankaran. 1989. Sorghum Leaf Area as a Function of Sixth Leaf Area. J. Agronomy \& Crop Science 162, 300-304

Gaspersz, V. 1995. Teknik Analisis Dalam penelitian Percobaan. Jilid 1. Tarsito. Bandung. Harris, K., P. K. Subudhi, A. Borrell, D. Jordan, D. Rosenow, H. Nguyen, P. Klein, R. Klein and J. Mullet. 2007. Sorghum stay-green QTL individually reduce post-flowering droughtinduced leaf senescence. Journal of Experimental Botany, Vol. 58, No. 2, pp. 327338.

Henzell, R.G., R.L. Brengman, D.S. Fletcher, and A.N. McCosker. 1992. Relationships between yield and non-senescence (stay-green) in some grain sorghum hybrids grown under terminal drought stress. In : M.A. Foale et al., (ed.) Proc. of the Second Australian Sorghum Conference. Gatton, Australia. 4-6 Feb. 1992. Occasional Publication no. 
68. Australian Inst. of Agric. Sci., Melbourne, Australia. 355-358.

Hoshikawa, K. 1990. Shinpen syokuryou sakumotsu. Section 9. Morokoshi. Youken-do, Tokyou. $338-352$.

Jorapur, R.M. and A.K. Rajvanshi. 1991. Alcohol distillation by solar energy. ISES Solar World Congress Proceedings, Vol. I. Part II. Pergamon Press. 772 - 777.

Jordan, D. R., C. H. Hunt, A. W. Cruickshank, A. K. Borrell and R.G. Henzell. 2012. The

Relationship Between the Stay-Green Trait and Grain Yield in Elite Sorghum Hybrids Grown in a Range of Environments. Crop Sci. Vol. 52 No. 3, p. 1153-1161

Kebede, H. P.K. Subudhi, D.T. Rosenow, H.T. Nguyen. 2001. Quantitative trait loci influencing drought tolerance in grain sorghum (Sorghum bicolor L. Moench). Theor Appl Genet. 103:266-276.

Medina-Sua'rez, R., K. Manning, J. Fletcher, J. Aked, C.R. Bird, and G.B. Seymour. 1997. Gene expression in the pulp of ripening bananas. Two-dimensional sodium dodecyl sulfatepolyacrylamide gel electrophoresis of in vitro translation products and cDNA cloning of 25 different ripening-related mRNAs. Plant Physiology 115, 453-461.

Metcalfe, D.S. and D.M. Elkins. 1980. Crop Production: Principles and Practices (4th edition). Macmillan Publishing.Co.Inc.

Murray, S.C., W. L. Rooney, M. T. Hamblin, S. E. Mitchell, and S. Kresovich. 2009. Sweet Sorghum Genetic Diversity and Association Mapping for Brix and Height. The Plant Genome 2:48-62.

Murty, D.S. and K.A. Kumar. 1995. Traditional uses of sorghum and millets. In: Dendy, D.A.V. (ed). Sorghum and Millets: Chemistry and Technology. American Association of Cereal Chemists, St Paul, MN, USA. 185 f\{221.

Mughogho, L.K., and S. Pande. 1984. Charcoal rot of sorghum. In: L.K. Mughogho (ed.) Sorghum root and stalk rots: A critical review. Proc. Consult. Group Discussion on Research Needs and Strategies for Control of Sorghum Root and Stalk Rot Diseases, Bellagio, Italy. 27 Nov.-2 Dec. 1983. ICRISAT, Patancheru. 11-24.

Nam, H.G. 1997. The molecular genetic analysis of leaf senescence. Current Opinion in Biotechnology 8, 200-207.

Pinaria, A., A. Baihaki, R. Setiamihardja, dan A. A. Daradjat. 1997. Selection Index of 53 Soybean Genotypes. Zuriat 8(2): 50-56.

Rosenow, D.T., and L.E. Clark. 1981. Drought tolerance in sorghum. In: Loden, H.D., and D. Wilkinson (editors). Proceedings of the 36th. Annual corn and sorghum industry research conference, 18-31.

Rosenow, D.T., J.E. Quisenberry, C.W. Wendt, and L.E. Clark. 1983. Drought tolerant sorghum and cotton germplasm. Agric. Water Manag. 7: 207-222.

Sabadin, P.K., M. Malosetti, M.P. Boer, F.D. Tardin, F.G. Santos, C.T. GuimaraÜes, R.L. Gomide, C.L.T. Andrade, P.E.P. Albuquerque, F.F. Caniato, M. Mollinari, G.R.A. Margarido, B.F. Oliveira, R.E. Schaffert, A.A.F. Garcia, F.A. van Eeuwijk, and J.V. Magalhaes. 2012. Studying the genetic basis of drought tolerance in sorghum by managed stress trials and adjustments for phonological and plant height differences. Theor Appl Genet. Published online: 02 February 2012. DOI 10.1007/s00122-012-1795-9. 
SPSS 16.0. 2007. SPSS 16.0 for Windows Release 16.0.1. November 15, 2007. SPSS Inc., $1989-2007$.

Sleper, D.A and J.M. Poehlman. 2006. Breeding Field Crops. Fourth Edition. Blackwell Publishing. 345-366.

Shehzad, T., H. Okuizumi, M. Kawase, and K. Okuno. 2009. Development of SSR-based sorghum (Sorghum bicolor (L.) Moench) diversity research set of germplasm and its evaluation by morphological traits. Genet Resour Crop Evol. Springer Science+Business Media B.V.

Singh, R., and B.D. Chaudary. 1979. Biometrical Methode For Quantitative Genetic Analysis. Kalyani Publishers. Ludhiana, New Delhi.

Stansfield, W.D. 1991. Theory and Problems of Genetics. Macmillan Pub. Co. Inc. New York.

Subudhi, P.K., D.T. Rosenow, H.T. Nguyen. 2000. Quantitative trait loci for the stay green trait in sorghum (Sorghum bicolor L. Moench): consistency across genetic backgrounds and environments. Theor Appl Genet. 101:733-741

Tao, Y.Z., R.G. Henzell, D.R. Jordan, D.G. Butler, A.M. Kelly, and C.L. Mclntyre. 2000. Identification of genomic regions associated with stay green in sorghum by testing RILs in multiple environments. Theor App/ Genet. 100:1225-1232

Thomas, H., and C.M. Smart. 1993. Crops that stay green. Ann. Appl. Biol. 123:193-219.

Thomas, H., and C.J. Howarth. 2000. Five ways to stay green. Journal of Experimental Botany, Vol. 51, GMP Special Issue. 329-337.

Tsuchihashi, N., and Y. Goto. 2005. Internode characteristic of sweet sorghum (Sorghum bicolor (L.) Moench) during dry and rainy season in Indonesia. Plant Prod. Sci. 8: 601 607.

Tsuchihashi, N., and Y. Goto. 2004. Cultivation of Sweet Sorghum (Sorghum bicolor (L.) Moench) and Determination of its Harvest Time to Make Use as the Raw Material for Fermentation, Practiced during Rainy Season in Dry Land of Indonesia. Plant Prod. Sci. $7: 442-448$

Wahdah, R., A. Baihaki, R. Setiamihardja, and G. Suryatmana. 1996. Variability and Heritability of Accumulation of Biomass on Soybean Seed. Zuriat7 (2): 92 - 98.

XU, W., D.T. Rosenow and H.T. Nguyen. 2000. Stay green trait in grain sorghum: relationship between visual rating and leaf chlorophyll concentration. Plant Breeding 119, 365 - 367. 